\title{
Avaliação do serviço de coleta para exame colpocitológico pela escala SERVQUAL
}

\author{
Evaluation of the collection service for colposcopy by the SERVQUAL scale
}

Evaluación del servicio de recolección para examen colpocitológico por la escala SERVQUAL

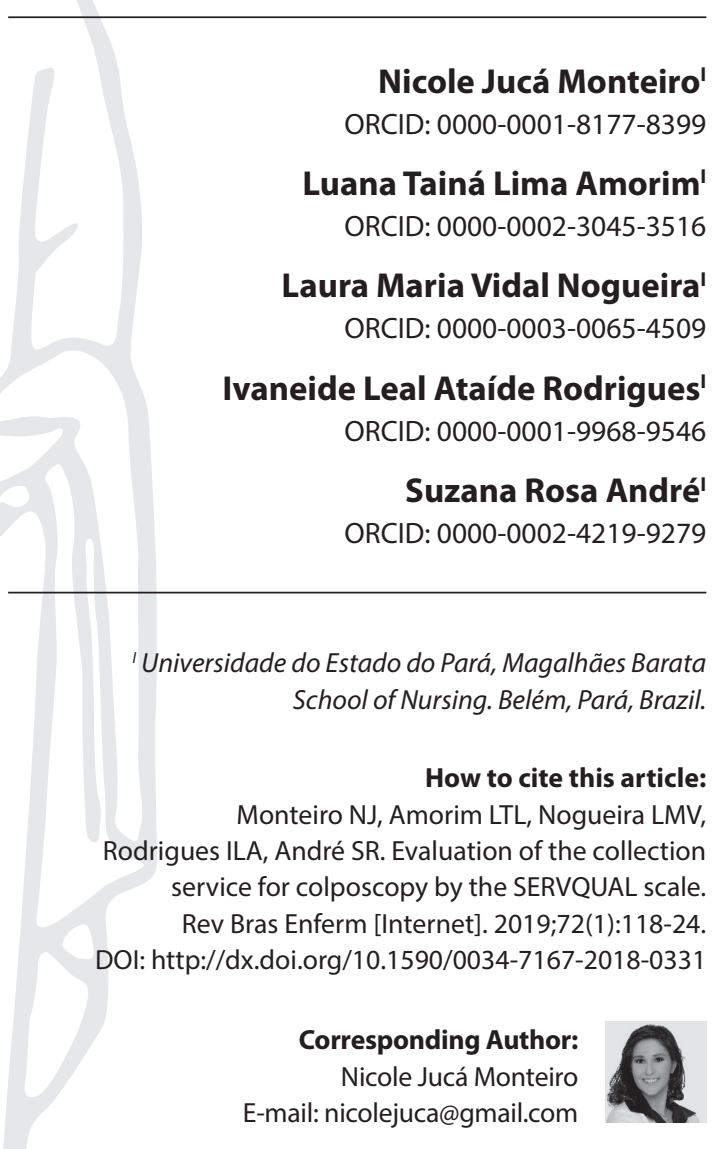

Submission: 05-15-2018

Approval: 07-23-2018

\begin{abstract}
Objective: To analyze women's perception of the quality of the service provided for colposcopy test in the city of Belém (PA), Brazil. Method: Quantitative-descriptive study on 400 women who underwent Pap test on the public healthcare network, using the Service Quality (SERVQUAL) model. We used the Cronbach's alpha index to measure the reliability of the scale, and data were analyzed by quartiles of the gaps of the dimensions: tangibility, responsiveness, reliability, assurance, and empathy. Results: The assurance dimension, corresponding to the knowledge and courtesy of staff, featured the highest degree of importance to users; and empathy, which corresponds to the staff's concern with women's needs, featured the lower degree. The most expressive negative gaps concerned the structure of services and the attitude of healthcare professionals when collecting the material. Conclusion: All gaps featured negative relationship between what was expected and perceived, expressing dissatisfaction regarding the service. Descriptors: Pap test; Nursing in Community Health Care; Quality Control; Cervix Uteri; Primary Health Care.
\end{abstract}

\section{RESUMO}

Objetivo: Analisar a percepção de mulheres acerca da qualidade do serviço de colpocitologia oncótica em Belém (PA). Método: Estudo quantitativo-descritivo com 400 mulheres que realizaram o exame de colpocitologia oncótica na rede pública de saúde, utilizando o modelo Service Quality (SERVQUAL). Utilizou-se o Alpha de Cronbach para medir a confiabilidade da escala, e os dados foram analisados pelos quartis dos gaps das dimensões: tangibilidade, responsividade, confiabilidade, credibilidade e empatia. Resultados: A dimensão credibilidade, correspondente ao conhecimento e cortesia dos funcionários, apresentou maior grau de importância para as usuárias, e a empatia, que corresponde à preocupação demonstrada pelos funcionários com as necessidades das mulheres, exibiu menor grau. Os gaps negativos mais expressivos dizem respeito à estrutura dos serviços e a atitude dos profissionais por ocasião da coleta de material. Conclusão: Todos os gaps apresentaram relação negativa entre o esperado e o percebido expressando a insatisfação em relação ao serviço.

Descritores: Teste de Papanicolau; Enfermagem em Saúde Comunitária; Controle de Qualidade; Colo de Útero; Atenção Primária à Saúde.

\section{RESUMEN}

Objetivo: Analizar la percepción de mujeres acerca de la calidad del servicio de colpocitología oncótica en Belém (PA). Método: Estudio cuantitativo-descriptivo con 400 mujeres que realizaron el examen de colpocitología oncótica en la red pública de salud, utilizando el modelo Service Quality (SERVQUAL). Se utilizó el Alpha de Cronbach para medir la confiabilidad de la escala, y los datos fueron analizados por los cuartiles de los gaps de las dimensiones: tangibilidad, responsividad, confiabilidad, credibilidad y empatía. Resultados: La dimensión credibilidad, correspondiente al conocimiento y a la cortesía de los funcionarios, presentó mayor grado de importancia para las usuarias; $y$ la empatía, que corresponde a la preocupación demostrada por los funcionarios con las necesidades de las mujeres, exhibió menor grado. Los gaps negativos más expresivos se refieren a la estructura de los servicios y a la actitud de los profesionales con ocasión de la recolección del material. Conclusión: Todos los gaps presentaron relación negativa entre lo esperado y lo percibido expresando la insatisfacción con relación al servicio. Descriptores: Prueba de Papanicolaou; Enfermería en Salud Comunitaria; Control de Calidad; Cuello del Útero; Atención Primaria de Salud. 


\section{INTRODUCTION}

High rates of morbidity and mortality of women due to cervical cancer in Brazil corroborate a serious problem of public health, highlighting that the (lack of) structure of the services directly influences on the quality of service provided to users, to achieve goals established for the service and, consequently, on cancer control. Quality of the service is a paramount factor for greater benefits to the population's health ${ }^{(1)}$.

In regions with high incidence of cervical cancer there are usually deficient screening programs, which culminate in deficits in surveillance systems, hindering the knowledge about the actual epidemiological situation of this pathology ${ }^{(2)}$.

According to the estimate of the Brazilian National Cancer Institute (INCA) for 2018/2019, about 640 thousand new cases of cancer, except non-melanoma skin cancer, should be reported in the country. In the Northern region, cervical cancer is the third most incident type among women, with occurrence of 7.38 cases for every group of 100 thousand inhabitants ${ }^{(3)}$.

Screening of cervical cancer is performed in the Primary Healthcare Network considering results of the Pap test. In this sense, the perception of women/patients of the provided service consists in an important evaluation strategy, both to improve the daily life of the services and the management, in order to assist in the identification of expectations and needs, thus contributing to the planning of healthcare services ${ }^{(4)}$.

Dissatisfaction concerning the quality of the health care may result in women not coming back to the healthcare center, or in searching for such service only in extreme situations, thus causing overcrowding in hospitals, ER units, in case of urgencies and emergencies, among others. On the other hand, high levels of satisfaction on the part of users of primary healthcare units may lead to greater retention and confidence in the service, in such a way to ensure that the service is always sought in its primary level, avoiding greater harms to women's health and quality of life ${ }^{(5)}$.

Thus, we formulated the following question: are the public primary healthcare services satisfactory to women who seek to collect material for the Pap test?

\section{OBJECTIVE}

To analyze women's perception of the quality of the material collection service for Pap test in primary healthcare units.

\section{METHOD}

\section{Ethical aspects}

The study was conducted according to Resolution no. 466/12, of the National Council of Health/Brazilian Ministry of Health, and it was approved by the Research Ethics Committee of the Undergraduate Program in Nursing of the State University of Pará. The research was authorized by the Municipal Department of Health of Belém.

\section{Study design, location, and period}

Descriptive study with quantitative approach, carried out in seven primary healthcare units of the public healthcare network of the city of Belém (PA), corresponding to $10 \%$ of the total primary healthcare units. Belém is divided into eight administrative districts, and seven of which have primary healthcare units. Units chosen for the study represent each of the districts, and the choice criterion was featuring higher demand.

Data were collected between November 2016 and August 2017, using the Service Quality questionnaire (SERVQUAL) validated by their creators: Parasuraman, Zeithaml, and Berry, being a world-renowned method $^{(6)}$. Designed to be applicable to any type of service, the authors themselves defend necessary adaptations. In Brazil, SERVQUAL has been satisfactorily used in the evaluation of healthcare services. For our study, we semantically adapted it in order to related it to the colposcopy service. The same structure of the questionnaire was maintained, with the assessment of five dimensions.

Such dimensions concern evaluation criteria of the quality of a service, namely: tangibility, reliability, responsiveness, assurance, and empathy. Tangibility corresponds to physical characteristics of the location such as equipment, staff, and available materials. Reliability is the ability of the professionals to safely and efficiently provide their service. Responsiveness is characterized as the availability of professionals to voluntarily attend users in an attentive way, with precision and fast response time. Assurance comprises the healthcare professionals' knowledge and their ability to convey confidence. Empathy includes accessibility, sensitivity, and efforts to understand the users' needs ${ }^{(7)}$.

The questionnaire is organized, aesthetically, with two parallel columns to record women's opinion before and after the Pap test, in order to measure their expectation and perception concerning the service. As for score, we established a scale ranging from 1 to 5 . It is noteworthy that the original scale was developed with a range from 1 to 7 points. However, authors of a study ${ }^{(8)}$ concluded that obtaining good results does not depend on ranging of numbers.

\section{Population or sample; inclusion and exclusion criteria}

Study sample consisted of 400 women, aging from 25 to 60 years, considered as priority to undergo the Pap test. In Pará, 537,547 women are in the appropriate age group for undergoing the exam, according to INCA ${ }^{(9)}$. The sample was obtained from the following formula, assuming a sampling error of $5 \%$.

$$
\begin{gathered}
n_{0=\frac{1}{(0,05)^{2}}}=400 \\
=\frac{537.547 \times 400}{537.547+400} \cong 400
\end{gathered}
$$

We considered as inclusion criteria: women living in the capital of Pará; in the age group prioritized for undergoing examination, according to INCA; spontaneous search for public primary healthcare services for undergoing the test. Exclusion criteria were: women who were passing through the unit, and with cognitive impairments as impediments for answering questions of the data collection instrument.

\section{Research protocol}

Data were collected in two steps: firstly, before conducting the test in order to measure women's expectations; and secondly, after completing the exam to measure their perception of the 
provided service. Women's responses were recorded by observing a scale from 0 to 5, namely: 1 (fully disagree); 2 (disagree); 3 (neutral); 4 (agree); 5 (fully agree). Hence, if users checked "fully agree," they would be assigning a 5 rate to the item.

\section{Data analysis and statistics}

We analyzed the obtained data using the Microsoft Excel 2010 program. First, we analyzed the reliability level of the questionnaires by the Cronbach's a, as shown in Chart 1 .

Chart 1 - Classification of reliability considering Cronbach's a values

\begin{tabular}{|c|c|c|c|c|c|}
\hline Reliability & Very low & Low & Moderate & High & Very high \\
\hline Value of $a$ & $a<0,30$ & $0,30 \leq a<0,60$ & $0,60 \leq a<0,75$ & $0,75 \leq a<0,90$ & $0,90 \leq a$ \\
\hline
\end{tabular}

Then, we analyzed the discrepancy (gaps) between women's expectations and perceptions regarding the provided service, being the "gap" a measure of the quality of the service concerning a specific feature that allowed showing possible flaws in the process of quality management ${ }^{(11)}$.

Hence, we identified five gaps: 1) distance between users' expectation and perception regarding healthcare units, which directly impact on the evaluation of the quality of the service on their part; 2 ) difference between the perception of healthcare units considering users' expectations and specifications of the quality of the service, from the users' point of view; 3 ) differences between the quality specifications in a certain service and the effectively provided service, which affect the perceived quality of service on the part of users; 4) difference between the provided service and the promise of external communication between healthcare units; and 5) women's perceptions about the quality of the service, depending on the magnitude of the difference between the expected service and the provided service perceived by them. The last gap outstands because it synthesizes the occurrence of one or more gaps, which is why it comprises the basis for developing the SERVQUAL model.

Analysis of gaps involved their diagnosis, determined by the issues comprising quality dimensions. For calculating the gaps, we used the following formula: Gap = Satisfaction - Importance ${ }^{(11)}$. The higher the gap of the presented item, the greater the discrepancy between the expected service (expectation) and the perceived service (perception directly resulted from the effectiveness of the provided service). These gaps are major obstacles in an attempt to achieve a level of excellence in the provision of healthcare services ${ }^{(12)}$.

Gap 1 is caused by the underestimation, on the part of healthcare units, in meeting the users' expectations. Gap 2, on the other hand, is caused by the lack of true commitment of healthcare units with quality. As for Gap 3, it is caused by the unwillingness or inability of areas dealing with people to be aware of the standards, even though considering that any activity involving people is difficult to standardize. Gap 4 is believed to be caused by the lack of balance between attractiveness and possibility of providing health care on the part of the system; and Gap 5 is caused by internal quality issues towards healthcare professionals.

To identify items that compromised women's perception regarding the quality of the provided service, we analyzed quartiles, a measure of central tendency that allowed us classifying the priority of each item according to their criticality, considering four classes to do so, namely: critical, high, moderate, and low priority. For calculating quartiles, we used the following formula: Quartile = Perception - Expectation ${ }^{(13)}$.

\section{RESULTS}

A total of 400 women participated in the study. They aged between 25 and 65 years, being the highest prevalence for the age group between 25 and 35 years, with 122 users (30\%); the others are distributed as follows: 36 to 45 years -111 users (28\%); 46 to 55 years - 93 users ( $23 \%)$; and 56 to 65 years -74 users (19\%). Regarding ethnicity: mixed race -241 users (60\%); white - 90 users (22\%); black - 67 users (17\%); and yellow -2 users (1\%). Schooling had the highest prevalence as for high school, corresponding to 156 users (39\%), followed by some elementary school -86 users (21\%); some high school - 54 users (14\%); elementary school -49 users (12\%); some college - 20 users (5\%); and college - 35 users (9\%).

Of the participants, 363 (91\%) have already undergone the test at other times, and 337 (84\%) stated that they undergo it periodically as a means of prevention and diagnosis of cervical cancer; 53 (13\%) women have sporadically undergone the examination, and 10 (3\%) had never undergone it.

Concerning the location for undergoing the examination, 275 $(69 \%)$ users stated that they always do it in public healthcare services, and 125 (31\%) reported that they had already done it in private clinics, having as justification the delay for getting the results, little reliability in the medical report, and the best provision of health care on the part of professionals.

Chart 2 - Cronbach's a values of the studied dimensions

\begin{tabular}{|c|c|}
\hline \multicolumn{2}{|c|}{ Cronbach's a } \\
\hline Dimensions & Cronbach's a \\
\hline Tangibility & 0.662 \\
\hline Responsiveness & 0.753 \\
\hline Reliability & 0.426 \\
\hline Assurance & 0.552 \\
\hline Empathy & 0.768 \\
\hline Cronbach's a of total scale & 0.892 \\
\hline
\end{tabular}

From the results obtained in Chart 2, we found a high degree of reliability of the used questionnaire $(\alpha=0.892)$, confirming internal consistency as for the 20 items of the SERVQUAL scale, enabling recognizing the feasibility of its use in primary health care, more specifically concerning services for collecting material for the Pap test. However, to individually evaluate each dimension, a values indicated low reliability for the following dimensions: reliability ( $a=$ $0.426)$ and assurance $(a=0.552)$; moderate reliability for tangibility $(a=0.662)$; and high reliability for responsiveness $(a=0.753)$ and empathy $(a=0.768)$.

According to Chart 3, the Assurance dimension - that is, the knowledge and courtesy of the staff and the ability to convey confidence 
and safety to women - featured the highest degree of importance to users, since the mean expectation of components of such dimension accounted for 4.98 points from a total of 5 . Following, according to the degree of importance, the Tangibility dimension, with mean expectation of 4.97, concerning the physical facilities, equipment, personnel, and communication materials. Reliability dimension also accounted for 4.97 mean expectation, and is related to the capacity of providing the intended service in a reliable and accurate way.

Chart 3 - Women's satisfaction level regarding the service

\begin{tabular}{|c|c|c|c|}
\hline \multicolumn{4}{|c|}{ Satisfaction level } \\
\hline Dimension & $\begin{array}{c}\text { Mean of } \\
\text { expectations }\end{array}$ & $\begin{array}{c}\text { Mean of } \\
\text { perceptions }\end{array}$ & $\begin{array}{c}\text { Users' satisfaction } \\
\text { level (\%) }\end{array}$ \\
\hline Tangibility & 4.97 & 3.98 & 80.08 \\
\hline Responsiveness & 4.94 & 4.21 & 85.22 \\
\hline Reliability & 4.97 & 4.65 & 93.56 \\
\hline Assurance & 4.98 & 3.87 & 77.71 \\
\hline Empathy & 4.92 & 3.98 & 80.89 \\
\hline \multicolumn{3}{|c|}{ Women's satisfaction level regarding healthcare units } & $83.49 \%$ \\
\hline
\end{tabular}

Chart 4 - Identification of gaps between users' expectations and perceptions

\begin{tabular}{|c|c|c|c|c|}
\hline \multicolumn{5}{|c|}{ Gaps } \\
\hline Dimension & Item & Expectation & Perception & Gap \\
\hline \multirow{4}{*}{ Tangibility } & 11 & 4.98 & 3.46 & -1.52 \\
\hline & 12 & 4.98 & 3.48 & -1.51 \\
\hline & 13 & 4.91 & 4.40 & -0.52 \\
\hline & 14 & 4.99 & 4.57 & -0.43 \\
\hline \multirow{4}{*}{ Responsiveness } & 15 & 4.98 & 4.84 & -0.14 \\
\hline & 16 & 4.95 & 4.16 & -0.79 \\
\hline & 17 & 4.98 & 4.13 & -0.85 \\
\hline & 18 & 4.84 & 3.72 & -1.13 \\
\hline \multirow{4}{*}{ Reliability } & 19 & 4.99 & 4.85 & -0.14 \\
\hline & 110 & 4.98 & 4.83 & -0.15 \\
\hline & 111 & 4.95 & 4.37 & -0.59 \\
\hline & 112 & 4.98 & 4.54 & -0.44 \\
\hline \multirow{4}{*}{ Assurance } & 113 & 5.00 & 4.82 & -0.17 \\
\hline & 114 & 4.99 & 3.53 & -1.46 \\
\hline & 115 & 4.99 & 2.96 & -2.03 \\
\hline & 116 & 4.96 & 4.16 & -0.80 \\
\hline \multirow{4}{*}{ Empathy } & 117 & 4.90 & 4.21 & -0.69 \\
\hline & 118 & 4.81 & 3.67 & -1.15 \\
\hline & 119 & 4.99 & 3.91 & -1.09 \\
\hline & 120 & 4.96 & 4.15 & -0.81 \\
\hline
\end{tabular}

Responsiveness - which refers to the availability of healthcare professionals to voluntarily attend the users, providing an attentive healthcare service, with precision and fast response time - and Empathy - which corresponds to the importance given when attending users and whether they are individually attended, thus demonstrating interest and specialized health care - were the ones featuring the lower mean expectations: 4.94 and 4.92, respectively.

Moreover, according to Chart 3, the dimension that most met women's expectations, with a $93.56 \%$ satisfaction level, was Reliability, whereas Assurance accounted for $77.71 \%$, thus being the lowest percentage according to the users. Level of total satisfaction of users in relation to healthcare units corresponded to $83.49 \%$.

From these results, we can proceed to the calculations of the gaps, thus expressing users' expectations and perceptions regarding the service (Chart 4). The total of women's responses to questions to which they were submitted resulted in negative gap values, indicating that the service provided in healthcare units did not meet their expectations.

Negative gaps demonstrated the evaluated items did not exceed/meet the users' expectations, expressing their dissatisfaction concerning the provided service/health care.

Chart 5 - Analysis of quartile considering the gaps

\begin{tabular}{|c|c|c|c|c|c|}
\hline \multicolumn{6}{|c|}{ Calculation of quartiles } \\
\hline Dimension & Item & Expectation & Perception & Gap & Quartile \\
\hline \multirow{5}{*}{$\begin{array}{l}\text { Critical } \\
\text { priority }\end{array}$} & 115 & 4.99 & 2.96 & -2.03 & \multirow{5}{*}{-1.14} \\
\hline & 11 & 4.98 & 3.46 & -1.52 & \\
\hline & 12 & 4.98 & 3.48 & -1.51 & \\
\hline & 114 & 4.99 & 3.53 & -1.46 & \\
\hline & 118 & 4.81 & 3.67 & -1.15 & \\
\hline \multirow{5}{*}{$\begin{array}{l}\text { High } \\
\text { priority }\end{array}$} & 18 & 4.84 & 3.72 & -1.13 & \multirow{5}{*}{-0.80} \\
\hline & 119 & 4.99 & 3.91 & -1.09 & \\
\hline & 17 & 4.98 & 4.13 & -0.85 & \\
\hline & 120 & 4.96 & 4.15 & -0.81 & \\
\hline & 116 & 4.96 & 4.16 & -0.80 & \\
\hline \multirow{5}{*}{$\begin{array}{c}\text { Moderate } \\
\text { priority }\end{array}$} & 16 & 4.95 & 4.16 & -0.79 & \multirow{5}{*}{-0.43} \\
\hline & 117 & 4.90 & 4.21 & -0.69 & \\
\hline & 111 & 4.95 & 4.37 & -0.59 & \\
\hline & 13 & 4.91 & 4.40 & -0.52 & \\
\hline & 112 & 4.98 & 4.54 & -0.44 & \\
\hline \multirow{5}{*}{$\begin{array}{l}\text { Low } \\
\text { priority }\end{array}$} & 14 & 4.99 & 4.57 & -0.43 & \\
\hline & I13 & 5.00 & 4.82 & -0.17 & \\
\hline & 110 & 4.98 & 4.83 & -0.15 & \\
\hline & 15 & 4.98 & 4.84 & -0.14 & \\
\hline & & 4.99 & 4.85 & -0.14 & \\
\hline
\end{tabular}


In Chart 5 we observe values of the quartiles of the obtained gaps, calculated with the inclusion of $25 \%$ of the evaluated items in each class (critical, high, moderate, and low priority). Results indicated that $40 \%$ of the most critical items, according to women's perception, correspond to the Credibility dimension group, which featured the highest mean as for degree of importance, according to users' expectation. We identified that $50 \%$ (two items) are of critical priority.

From the quartile analysis, we observed that the more negative gaps - consequently, those of critical priority - corresponded to:

I15 (Assurance): Healthcare units must provide the necessary support in such a way their employees fulfil their tasks.

I1 (Tangibility): Healthcare units must supply modern-looking equipment for conducting the examination.

I2 (Tangibility): The physical environment of the healthcare units should be pleasant.

I14 (Assurance): Healthcare professionals must be kind to me and to other professionals.

I18 (Empathy): I must feel I receive individualized health care.

\section{DISCUSSION}

Our results expressed women's global evaluation regarding the excellence or deficiency of healthcare services, being an attitude related, but not equivalent, to dissatisfaction, which resulted from a comparison of expectations with perceptions concerning the provision of the service. Assessment using SERVQUAL allowed women expressing their perceptions regarding the quality of the provided services as a whole, in addition to dimensions of such quality, making managers aware of the provided service in order to improve it ${ }^{(14)}$.

Identifying priority gaps allowed showing improvements that can help healthcare units, healthcare professionals, and managers in preparing a future Action Plan, which could allow correcting or at least mitigating the gaps we identified (Items I15, I1, I2, I14, and I8), based on the users' satisfaction level concerning the quality of the services currently provided.

Considering quality dimensions, the assessment pointed to a scenario of weaknesses related to lack of material resources for healthcare professionals to develop their activities; lack of a pleasant physical environment; availability of services in only one shift of the working hours of healthcare units; lack of modern equipment; and little kindness on the part of healthcare professionals in the service as a whole. However, we found strong points in relation to the material collection for colposcopy, namely: organization of materials for the examination; information on the part of the professionals of healthcare units concerning the days and the hours providing the service; capacity of the healthcare professional responsible for collecting the material in conveying confidence to conduct the test; and nursing professionals conveying confidence, demonstrating adequate knowledge about the examination procedures.

Analyzing the Assurance dimension allowed us to evidence the unavailability of the support required for properly developing professional activities, indicating that healthcare units should be responsible for providing a quality service to their users. To do so, an adequate physical infrastructure and availability of materials and proper equipment are essential to carry out the Pap test ${ }^{(15)}$.
In this sense, authors of study conducted in primary healthcare units of the Programa Saúde da Familia [Family Healthcare Program], in the city of São Paulo(16), in which they assessed the quality of the structure available for the nursing healthcare provided to children of up to one year of age, concluded that the structure suitable for providing health care enables good performance in the work process and good results concerning the health care provided to users. Nevertheless, a good infrastructure consists in an indirect indicator of the quality of the provided health care, being not totally sufficient. In addition, it is necessary to create quality control measures in primary healthcare units, in order to ensure the excellence of the examination ${ }^{(17)}$.

Moreover, in the Assurance assessment, we identified an unkind relationship between women and healthcare professionals at the time of collecting the material for the Pep test, according to the users' perception. Thus, it is noteworthy that healthcare professionals have the role of care providers, and their attitudes denote implications and repercussions for users. Hence, they must provide a respectful and dignified health care to women, prioritizing users' satisfaction concerning their professional relationship ${ }^{(18)}$

Authors of a study ${ }^{(19)}$ whose aim was to meet the barriers leading women in childbearing age to not undergo the colposcopy examination, from the perspective of the very women and healthcare professionals, concluded that one of the most recurrent feelings reported by women would be shame to undergo the test. Such fact may provoke negative feelings and insecurity in some women if these professionals provide health care in an unkind and unpleasant manner. Nevertheless, the better and the more education and attraction of women who are in the age group for the collection of the Pap exam, the greater will be the early solutions before a positive result for cancer ${ }^{(20)}$.

The evaluation of the Tangibility dimension brought evidences concerning the appearance of equipment used in the room for collecting the exam material, resulting in the women's perception as worn and obsolete materials. For a quality healthcare service there must be appropriate facilities both concerning availability of equipment necessary for providing the service and its modernization.

Authors of a study ${ }^{(21)}$ conducted to investigate the Programa de Melhoria do Acesso e da Qualidade da Atenção Básica (Program for Improving Access and Quality of Primary Health Care - PMAQ-AB), involving several Brazilian higher education institutions, whose objective was to describe and analyze the suitability of the structure and process of the PMAQ-AB staff for prevention of cervical cancer, concluded that the suitability of the structure, comprising the input equipment and material, varies between regions of the country. Percentage of healthcare units with appropriate structure was $40 \%$ in the Northern region, and about $60 \%$ in the Northeast, South, and Midwest regions, demonstrating that the Northern region features remarkable precariousness of structure related to the Pap test, thus influencing the satisfaction of women seeking healthcare services to undergo the examination.

In the context of Tangibility dimension, organization and reception observed in physical environments of the healthcare units were identified by women as inefficient and unpleasant. It is 
noteworthy the need to provide the users a quality environment, investing in the physical structure of healthcare units in such a way to produce greater motivation in women for them to seek the service and, therefore, undergo the Pap test ${ }^{(16,18)}$.

Concerning the evaluation of the Empathy dimension, we identified the women's need for receiving individualized health care, which is established by the principles of hospitality and respect for individuality in healthcare services. Users of healthcare services must always receive individualized treatment, in order for them to feel special and believe that the healthcare professional, in fact, cares about their specific needs. Health care must be provided in a relationship field respecting singular personalities, that is, each individual requires special attention concerning their needs, in such a way professionals provide health care without neglecting them, but respecting their individuality ${ }^{(19,22)}$.

Empathy allows you to experience feelings of another person as if being yours, being the careful and individualized health care its essence. In this sense, results of a study ${ }^{(16)}$ indicated that users of healthcare services were dissatisfied with the care provided by professionals, thus reflecting the poor attention given in the provided care.

The evaluation of the material collection services for Pap test is expressed in negative gaps in the five dimensions, an indication of dissatisfaction with the addressed healthcare services. Similar results were found in a study ${ }^{(23)}$ conducted in a colposcopy clinic in Scotland, when highlighting negative gaps in all five dimensions, being reliability the most expressive.

Furthermore, the analyzed dimensions can corroborate actions to implement healthcare services that provide material collection for Pap test in such a way to positively respond to screening practices of cervical cancer. Thus, they may enable early diagnosis of cancerous lesions, referring women to appropriate treatment, contributing to impact poor indicators of illness in the State of Pará, especially in the capital, Belém.

\section{Study limitations}

Only primary healthcare units were included, which constituted an important limitation, since the test is also carried out in some units of the Estratégia Saúde da Família (Family Health Care
Strategy - ESF), which have different physical structures from those in the aforementioned units. Therefore, broadening the study in such a way to include ESF users could change the results.

\section{Contributions to the field of nursing, health, or public policies}

Our results contribute to qualify the material collection service for Pap test and achieve the satisfaction of users, which may positively impact indicators of illness. In addition, such may be able to support the nursing staff and management of healthcare units in prioritizing the main actions that can help improving the service.

\section{CONCLUSION}

Women expressed dissatisfaction with the services for collecting material for the Pap test provided in the public primary healthcare network, according to the results obtained in gaps whose relationship between expectations and perceptions was negative.

By the analysis of the SERVQUAL dimensions, we demonstrated aspects that led to dissatisfaction in the users, probably making them uninterested in seeking the service. We observed a high degree of reliability in the applied questionnaire $(a=0.892)$, and we may confirm the feasibility of its use in primary health care, more specifically in services for collecting material for the Pap test.

In order to solve or mitigate problems responsible for users' dissatisfaction concerning services for collecting material for colposcopy, the infrastructure must be improved and modern equipment must be acquired. In addition, the necessary support for healthcare professionals performing the activity must be provided, among others, in order to increase users' satisfaction with the provided service, ensuring that women's perceptions exceed their expectations.

In this context, the level of response of the Primary Healthcare Network to examine women undergoing the Pap test is an aspect that must be valued in healthcare management and in the production of knowledge, since we can think about new strategies to improve and strengthen the link between healthcare units, their staff, and users, in such a way they embrace the cause concerning the importance of undergoing such examination in the fight against cervical cancer.

\section{REFERENCES}

1. Costa JHG, Souza IRA, Santos EJA, Prazeres BAP, Andrade ML, Melo MFC, et al. [Prevention of cervical cancer in riparian communities assisted by the Light in Amazonia Program in Pará State, Brazil]. Rev Pan-Amaz Saude [Internet]. 2011 [cited 2018 Oct 30];2(4):17-22. Available from: doi: 10.5123/S2176-62232011000400003 Portuguese.

2. Navarro C, Fonseca AJ, Sibajev A, Souza CIA, Araujo DS, Teles DAF, et al. Cervical cancer screening coverage in a high-incidence region. Rev Saúde Pública [Internet]. 2015 [cited 2018 Oct 30];49:17. Available from: doi:10.1590/S0034-8910.2015049005554

3. Ministério da Saúde (BR), Instituto Nacional do Câncer José Alencar Gomes da Silva (INCA). Estimativa 2018: incidência de câncer no Brasil. Rio de Janeiro: INCA; 2017 [cited 2018 Nov 3]. 130 p. Available from: http://www.inca.gov.br/estimativa/2018/estimativa-2018.pdf

4. Sena ALC, Ferreira LN, Oliveira RS, Kozmhinsky VMR. [Embracement and satisfaction of the user in the family health strategy: a successful experience]. Rev APS [Internet]. 2015 [cited 2018 Oct 30];18(2):134-140. Available from: https://aps.ufjf.emnuvens.com.br/aps/article/ view/2326/871 Portuguese

5. Montenegro, LC. A expressão da ética nas práticas de profissionais da saúde no contexto de unidades de internação hospitalar [Thesis on the Internet]. Belo Horizonte (MG): Universidade Federal de Minas Gerais, Escola de Enfermagem, Colegiado de Pós-Graduação; 2014 [cited 
Evaluation of the collection service for colposcopy by the SERVQUAL scale Monteiro NJ, Amorim LTL, Nogueira LMV, Rodrigues ILA, André SR.

2018 Nov 3]. 146 p. Available from: http://www.enf.ufmg.br/pos/defesas/655D.PDF

6. Cruz WBS, Melleiro MM. Assessment levels of the user's satisfaction in a private hospital. Rev Esc Enferm USP [Internet]. 2010 [cited 2018 Oct 30];44(1):145-51. Available from: http://dx.doi.org/10.1590/S0080-62342010000100021

7. Pena MM, Silva EMS, Tronchin DMR, Melleiro MM. The use of the quality model of parasuraman, zeithaml and berry in health services. Rev Esc Enferm USP [Internet]. 2013 [cited 2018 Oct 30];47(5):1227-32. Available from: doi: 10.1590/S0080-623420130000500030

8. Reis ICS. A escala servqual modificada: avaliação da qualidade percebida do serviço de lazer oferecido por um complexo poliesportivo num parque florestal [dissertação]. Florianópolis (SC): Universidade Federal de Santa Catarina, Programa de Pós-Graduação em Engenharia de Produção; 2001 [cited 2018 Nov 3]. 141 p. Available from: http://few.universoef.com.br/container/gerenciador_de_arquivos/arquivos/147/aescala-servqual.pdf

9. Ministério da Saúde (BR), Instituto Nacional do Câncer José Alencar Gomes da Silva (INCA). Estimativa 2016: incidência de câncer no Brasil [Internet]. Rio de Janeiro: INCA; 2015 [cited 2018 Nov 3]. 126 p. Available from: http://santacasadermatoazulay.com.br/wp-content/ uploads/2017/06/ estimativa-2016-v11.pdf

10. Malhotra NK. Pesquisa de Marketing. São Paulo: Bookman; 2008. 230 p.

11. Miguel MC, Freire VF. Avaliação da qualidade orientada ao usuário do museu capixaba do negro: aplicação da abordagem teórico metodológica servqual em um espaço museológico de Vitória-ES. Rev Guará [Internet]. 2016 [cited 2018 Oct 30];5:103-16. Available from: http://periodicos.ufes.br/guara/article/view/14350/10092

12. Berry LL; Parasuraman A. Serviços de marketing: competindo através da qualidade. São Paulo: Maltese Norma; 1992.

13. Reis KA, Ramires VRM. A qualidade em serviços na perspectiva do usuário: avaliação quantitativa da satisfação dos clientes de um laboratório de análises clínicas em Belém-PA [Monography]. Belém: Universidade do Estado do Pará; 2015.

14. Pelissari AS, Solis DR, lanagui EC, Gonzalez IVFP, Setubal FMR. [Application and assessment of the servqual model to analyze the quality of the service]. Rev Cient Intern [Internet]. 2012 [cited 2018 Oct 30];1(1):1-24. Available from: d.o.i: http://dx.doi.org/10.6020/1679-9844/2301 Portuguese.

15. Saparolli ECL, Adami NP. Evaluation of nursing consultation structure for children in primary health care. Rev Esc Enferm USP [Internet]. 2010 [cited 2018 Oct 30];44(1):91-7. Available from: http://dx.doi.org/10.1590/S0080-62342010000100013

16. Silva AAF. A percepção da qualidade do serviço e a satisfação dos usuários das unidades básicas de saúde de Caraguatatuba [Monography in the Internet]. Caraguatatuba (SP): Instituto Federal de Educação, Ciência e Tecnologia; 2016 [cited 2018 Nov 3]. 85 p. Available from: http://www.ifspcaraguatatuba.edu.br/wp-content/uploads/2016/09/2-Andrea.pdf

17. Darwish YM, Garvin AD; Johnston CM, Zoschnick L, Conners A, Laing S, et al.. An Assessment of Gynecological Cytology Screening Practices Among Health Care Providers Nationwide. Arch Pathol Lab Med. 2015;139(5):650-5. doi: 10.5858/arpa.2013-0620-OA

18. Mendes F, Mantovani MF, Gemito ML, Lopes MJ. [User satisfaction with primary health care]. Rev Enf Ref [Internet]. 2013 [cited 2018 Oct 30];3:17-25. Available from: http://www.scielo.mec.pt/pdf/ref/vserllln9/serllln9a02.pdf Portuguese.

19. Aguilar RP, Soares DA. [Barriers to pap smear: prospects for users and professionals of the family health strategy in vitória da conquista-BA]. Physis [Internet]. 2015 [cited 2018 Oct 30];25(2):359-79. Available from: http://dx.doi.org/10.1590/S0103-73312015000200003 Portuguese.

20. Fabrin GVI, Motter N, Weber AV, Menezes DV, Munareto AA, Martins AP, et al. Análise do atendimento e satisfação dos clientes: estudo de caso de um laboratório escola. Saúde Integr [Internet]. 2016 [cited 2018 Oct 30];9(17):117-25. Available from: http://local.cnecsan.edu.br/ revista/index.php/saude/article/view/369/296

21. Marques JM, Ramos ESF. [Nurse's action against colophochological examination]. Rev Educ Meio Amb Saú [Internet]. 2017 [cited 2018 Oct 30]:7(2):48-59. Available from: http://faculdadedofuturo.edu.br/revista1/index.php/remas/article/view/140/221 Portuguese.

22. Tomasi E, Oliveira TF, Fernandes PAA, Thume E, Silveira DS, Siqueira FV, et al. [Structure and work process in the prevention of cervical cancer in health basic attention in Brazil: program for the improvement of access and quality]. Rev Bras Saúde Matern Infant [Internet]. 2015 [cited 2018 Oct 30];15(2):171-80. Available from: http://dx.doi.org/10.1590/S1519-38292015000200003 Portuguese.

23. Wisniewski M, Wisniewski H. Measuring service quality in a hospital colposcopy clinic. Int J Health Care Qual Assur [Internet]. 2005 [cited 2018 Oct 30];18(3):217-28. Available from: http://dx.doi.org/10.1108/09526860510594776 